\title{
KESIAPAN PELAKSANAAN PEMBELAJARAN TATAP MUKA DI SMK NEGERI 2 TORAJA UTARA PADA MASA PANDEMI
}

\author{
Oce Payung Limbong ${ }^{1}$, Witarsa Tambunan ${ }^{2}$, Mesta Limbong ${ }^{3}$
}

${ }^{1}$ Mahasiswa Magister Administrasi Pendidikan PPs-UKI, Jakarta, Indonesia, ${ }^{2}$ Dosen Magister Administrasi Pendidikan PPs -UKI, Jakarta Indonesia, ${ }^{3}$ Dosen Magister Administrasi Pendidikan PPs -UKI, Jakarta Indonesia

e-mail: witarsa.oke@gmail.com, mesta.limbong@uki.ac.id

\begin{tabular}{l|l|l} 
Received : Januari, 2021 & Accepted : Januari, 2021 & Published : Januari, 2021
\end{tabular}

\begin{abstract}
The purpose of this study was to determine the readiness for face-to-face learning at SMK Negeri 2 Toraja Utara. The analysis used in this study is a qualitative analysis using the subject matter approach. In order for maximum face-to-face learning readiness, school leaders must involve teachers, school committees and parents of students at the meeting to determine face-to-face learning procedures and send the results of determining face-to-face learning for parents who do not attend meetings so that learning procedures are clear so that learning readiness is maximized resulting in learning objectives can be achieved. From the results of this study it can be concluded that the readiness for face-to-face learning at SMK Negeri 2 Toraja Utara has not been maximized because at the meeting to determine the procedure for determining face-to-face learning, it was only attended by a few parents of students and there were also some teachers who were not present at the meeting.
\end{abstract}

Keywords: readiness, face to face learning, pandemic

\begin{abstract}
Abstrak
Tujuan penelitian ini adalah untuk mengetahui kesiapan pelaksanaan pembelajaran tatap muka di SMK Negeri 2 Toraja Utara. Analisis yang digunakan dalam penelitian ini adalah analisis kualitatif dengan menggunakan pendekatan pokok masalah. Agar kesiapan pelaksanaan pembelajaran tatap muka maksimal maka pimpinan sekolah harus melibatkan guru, komite sekolah dan orang tua siswa pada rapat penetapan prosedur pembelajaran tatap muka dan mengirim hasil penentuan pembelajaran tatap muka bagi orang tua yang tidak mengikuti rapat agar prosedur pembelajaran jelas sehingga kesiapan pembelajaran menjadi maksimal mengakibatkan tujuan pembelajaran dapat tercapai. Dari hasil penelitian ini dapat disimpulkan bahwa kesiapan pembelajaran tatap muka di SMK Negeri 2 Toraja Utara belum maksimal oleh karena pada saat rapat penentuan prosedur penetapan pembelajaran tatap muka hanya dihadiri oleh beberapa orang tua siswa dan juga ada beberapa guru yang tidak hadir dalam rapat tersebut.
\end{abstract}

Kata Kunci: kesiapan, pembelajaran tatap muka, pandemi

Citation: Limbong, O. P., Tambunan, W., \& Limbong, M. (2021). KESIAPAN PELAKSANAAN PEMBELAJARAN TATAP MUKA DI SMK NEGERI 2 TORAJA UTARA PADA MASA PANDEMI. Jurnal Manajemen Pendidikan, 10(1), 37-45. Retrieved from http://ejournal.uki.ac.id/index.php/jmp/article/view/3265 


\section{PENDAHULUAN}

Covid-19 telah membawa dampak pada seluruh sektor kehidupan manusia, tak terkecuali pada sektor pendidikan. Sudah beberapa bulan lembaga-lembaga pendidikan harus melakukan pembelajaran jarak jauh (PJJ) secara daring. Untuk mencegah penularan virus Covid 19 di sekolah maka protokol kesehatan di merupakan aturan hal yang paling penting untuk dilakukan. Dalam buku Panduan Penyelenggaraan Pembelajaran di Masa Pandemi Covid-19 yang disusun empat menteri dikatakan bahwa pembelajaran tatap muka dilaksanakan melalui dua fase yakni masa transisi dan masa kebiasaan baru atau new normal. Pembelajaran tatap muka di satuan pendidikan pada zona hijau dilakukan dengan penentuan prioritas berdasarkan jenjang pendidikan yang lebih tinggi terlebih dahulu dan mempertimbangkan kemampuan peserta didik untuk menerapkan protokol kesehatan dan menjaga jarak (physical distancing) dalam melaksanakan pembelajaran tatap muka di satuan pendidikan(Kemdikbud, 2020). Proses pembelajaran dari rumah melalui pembelajaran online idealnya tetap dapat mengakomodasi kebutuhan belajar siswa untuk mengembangkan bakat dan minat sesuai dengan jenjang pendidikannya (Shaleh, Muh., Anhusadar, La Ode, 2021). Nadiem menekankan, pembelajaran tatap muka secara terbatas tidak harus menunggu Juli 2021, jika tenaga pendidik di sekolah sudah menjalani vaksinasi. "Tidak ada kebijakan pembelajaran tatap muka terbatas di bulan Juli 2021, pembelajaran tatap muka terbatas mulai sekarang. Sekarang sudah divaksinasi guru-gurunya, sekolah yang guru-gurunya sudah divaksinasi harus segera memenuhi protokol kesehatan dan segera lakukan tatap muka," kata Nadiem dalam konferensi pers secara virtual, Selasa (30/3/2021). Sejak Januari 2021, ada 22 persen satuan pendidikan sudah melaksanakan pembelajaran tatap muka terbatas yang keputusannya ada di pemerintah daerah (pemda) masing-masing.(Nadim dalam Kompas.com, 31/03/2021, 07:17 WIB).

Pembelajaran tatap muka memang sangat mendukung bagi sebagian siswa karena kemampuan siswa terbatas pada Online. Namun sebagian orang tua tidak setuju dengan adanya pembelajaran tatap muka karena masih ada kluster Covid-19. Alasan orang tua berpendapat karena anakanak belum bisa sepenuhnya mentaati dan bertindak sesuai dengan protokol kesehatan. Orang tua khawatir ketika nanti di sekolah, siswa tidak bisa melaksanakan social distancing atau jaga jarak dengan teman-temannya, tidak sepenuhnya memakai masker, dan belum bisa sepenuhnya menjaga kebersihan diri dari lingkungan sekitar(Sabiq, A. F. (2020:186). Pembelajaran tatap muka (face to face) yaitu seperangkat tindakan secara terencana berdasarkan kaidah-kaidah pembelajaran yang berupa proses interaksi antara peserta didik, materi pembelajaran, guru, dan lingkungan sehingga guru lebih mudah untuk mengevaluasi sikap siswa(Nurlatifah, N., Ahman, E., Machmud, A., \& Sobandi, A. (2021).

Pelaksanaan pembelajaran tatap muka di SMK Negeri 2 Toraja Utara telah berlangsung sejak bulan Januari 2021 sampai sekarang. Kegiatan ini dilakukan karena melihat kondisi pelaksanaan pembelajaran online tidak berjalan dengan baik oleh karena kurangngnya dukungan dari berbagai aspek. Kendala yang dihadapi adalah sarana dan prasarana tidak memadai, biaya penggunaan internet dan jaringan kurang memadai serta dukungan orang tua terhadap pembelajarn online masing kurang. Hal inilah yang mendorong pelaksanaan pembelajaran tatap muka di SMK Negeri 2 Toraja Utara dengan melaksanakan berbagai persiapan sebelum pelaksanaan sehingga sampai hari ini masih terus berjalan. Sehingga penulis perlu menganalisis kesiapan pelaksanaan pembelajaran tatap muka yang tergambar dalam analisis pokok masalah melalui analisis pohon masalah, analisis pohon sasaran dan analisis pohon alternative.

Berdasarkan penjelasan dari permasalahan di atas maka rumusan masalah dari penelitian ini adalah bagaimana kesiapan pelaksanaan pembelajaran tatap muka di SMK Negeri 2 Toraja Utara. Tujuan dari penelitian ini adalah untuk mengetahui kesiapan pelaksanaan pembelajaran tatap mika di SMK Negeri 2 Toraja Utara

Masa Pandemi 
Pandemi Covid-19 telah melanda hampir seluruh dunia. Kisah penyebarannya berbeda-beda di masing-masing Negara. Dampak yang ditimbulkan telah mengubah berbagai aspek kehidupan. Di bidang pendidikan sangat merasakan dampak dari adanya penyebaran Virus Covid-19.Pemerintah terus mengggalakkan berbagai cara agar pembelajaran tetap berlangsung. Pembelajaran online adalah solusi bagi terlaksananya pendidikan di masa pandemi(Herliandry\&Nurhasanah \& Suban\& Kuswanto, 2020:66). Selain memberi solusi, pembelajaran online juga memberikan tantangan yang luar biasa bagi dunia pendidikan. Tantangan mengenai pembelajaran online dialami oleh semua kalangan baik peserta didik, guru, orang tua, masyarakat bahkan pemerintah. Walaupun kondisi ini memberikan tantangan namun inilah yang harus dilakukan agar pembelajaran tetap berlangsung. Pembelajaran online terjadi dimana pendidik dan peserta didik berada di tempat terpisah namun interaksi tetap berjalan dengan baik. Menurut Gunawan, Suranti, \& Fathoroni. (2020) pemanfaatan aplikasi, website media social dan learning management system sangat penting pada pembelajaran online.

Pada masa pandemic sekarang ini, factor lingkungan belajar sangat berpengaruh pada pada setiap siswa, siswa yang berada di pelosok desa dengan keadaan keluarga yang penuh dengan keterbatasan baik dalam hal pendidikan maupun teknologi tentu akan sangat berbeda dengan siswa yang berada di kota dengan pendidikan kelurga yang baik dalam mengakses pembelajaran online tersebut.

Dari uraian di atas dapat dikatakan bahwa pandemi covid-19 mempengaruhi keberlangsungan pendidikan dimana peserta didik berada di tempat terpisah dengan pendidik dan yang menjadi solusi dalam pembelajaran adalah pembelajaran online dengan memanfaatkan berbagai teknologi berupa aplikasi ,media sosial, learning management system, dan lain-lain. Pembelajaran Tatap Muka

Pembelajaran tatap muka adalah salah satu solusi bagi siswa yang mengalami kendala dalam pembelajaran online. Pembelajaran tatap muka pada masa pandemi sekarang ini menuai kontraversi dari berbagai kalangan masyarakat. Sebagian besar orang tua, siswa dan guru menginginkan pembelajaran dilaksanakan dengan tatap muka. Sesuai dengan surat edaran empat menteri bahwa pembelajaran tatap muka dapat dilakukan di daerah Zona Hijau dengan menggunakan metode tatap muka terbatas dimana siswa di bagi sesi sehingga jumlah dalam kelas berkurang dan waktu yang digunkan dipersingkat dengan tetap mengutamakan kesehatan dan keselamatan semua warga satuan pendidikan. Pembelajaran tatap muka adalah pembelajaran kelas yang terjadi dikelas dan mengandalkan kehadiran dosen pengajar untuk mengajar dan mahasiswa terlibat langsung dalam komunikasi verbal spontan pada lingkungan fisik(Anggrawan,2019).Menurut Norman(2016) kehadiran mahasiswa dalam pembelajaran tatap muka di kelas mempengaruhi psikologis, emosional dan mampu menyerap pembelajaran serta langsung mendapatkan solusi jika ada masalah yang terjadi dalam pembelajaran (Wekke \& Saleh, 2020) Jadi dari uraian di atas dapat disimpulkan bahwa pembelajaran tatap muka adalah solusi bagi siswa yang mengalami kendala dalam pembelajran daring, di mana pembelajaran berlangsung dikelas, terjadi interaksi antara pendidik dan peserta didik yang secara langsung dapat mempengaruhi psikologis dan emosional peerta didik sehingga mampu menyerap pembelajran dengan baik

\section{Kesiapan Pelaksanaan Pembelajaran Tatap Muka}

Kesiapan merupakan kondisi di mana seseorang mampu memberi respon terhadap suatu situasi dengan menggunakan cara tertentu. Respon tersebut muncul dari dalam diri seseorang. Kemampuan untuk merespon berhubungan dengan kematangan, karena kematangan menunjukkan kesiapan untuk melaksanakan kecakapan (Jamal, 2020:17). Kesiapan dalam proses belajar sangat penting untuk menentukan keberhasilan pembelajaran. Banyak hal yang harus dipersiapkan pada pembelajaran di masa pandemi ini seperti guru, siswa, orang tua, materi yang akan diajarkan, pola tatap muka, sarana dan prasarana dan juga protokol kesehatan. 
Persiapan pembelajaran tatap muka dengan menetapkan protokol kesehatan sesuai ketetapan pemerintah dan menerapkan pola hidup bersih serta melibatkan orang tua dalam membuat aturan kepada peserta didik untuk mencegah penularan virus covid-19 di lingkungan sekolah(Shaleh \& Anhusadar, 2021:2165). Sesuai dengan surat kesepakatan empat menteri mengenai panduan penyelenggaraan pendidikan pada masa pandemic Covid-19, yang memperbolehkan pembelajaran tatap muka yang dilakukan secara bertahap di mulai dari tingkat SMA/SMK sampai pad tingkat TK. Hal ini dilakukan dengan memperhatikan urgensi yang terjadi pada pendidikan saat sekarang ini yaitu 1) Anak-anak terancam putus sekolah karena orang tua beranggapan bahwa pendidikan adalah tugas sepenuhnya pendidik dan proses pendidikan harus dilaksanakan dengan tatap muka dan juga sebagian anak terpaksa harus bekerja membantu orang tua memenuhi kebutuhan, sehingga tidak ada waktu untuk belajar. 2)Anak-anak kehilangan potensi untuk tumbuh kembang secara optimal pada masa emas pertumbuhan. 3)Tekanan psikososial yang dapat menimbulkan stress pada peserta didik karena kurangnya interaksi dengan lingkungan pendidikan dan sulitnya mengikuti pembelajaran jarak jauh(Nugroho, 2020:532)

Pelaksanaan pembelajaran tata muka mempertimbangkan beberapa hal, antara lain Tingkat resiko penyebaran virus covid-19, kesiapan fasilitas layanan kesehatan, kesiapan sekolah dalam pelaksanaan tatap muka, ketersediaan sarana transportasi yang aman, lingkungan dimana warga sekolah tinggal, akses belajar dari rumah, mobilitas warga, kebutuhan layanan pendidikan serta kondisi geografis satuan pendidikan. Sebelum pelaksanaan pembelajaran tatap muka, harus mendapat persetujuan dari petugas Covid-19, untuk memastikan seluruh protokol kesehatan tersedia dengan baik seperti sarana sanitasi dan kebersihan, fasilitas pelayanan kesehatan, penggunaan masker, thermogun, kondisi warga sekolah dan juga harus mendapat persetujuan dari komite sekolah dan orang tua siswa. Jadi untuk menjamin kesiapan pelaksanaan pembelajaran tatap muka harus memperhatikan berbagai aspek yaitu memperhatikan edaran pemerintah berserta dengan syarat yang harus dipenuhi dan juga urgensi yang terjadi dalam dunia pendidikan, harus melalui berbagai pertimbangan yang matang, harus melalui persetujuan petugas Covid-19 dengan berbagai syarat, ada persetujuan dengan komite sekolah dan orang tua siswa.

\section{METODE PENELITIAN}

Tujuan dari penelitian ini adalah untuk mengetahui kesiapan pelaksanaan pembelajaran tatap muka pada SMK Negeri 2 Toraja Utara dengan memperhatikan prosedur pembelajaran dari segi pengaturan jadwal pembelajaran, penetapan prosedur pembelajaran yang melibatkan guru dan orang tua dan memperhatikan surat edaran pemerintah (Dinas Pendidikan). Pelakasanaan penelitian ini dilaksankan di SMK Negeri 2 Toraja Utara pada bulan Februari 2021 Metode penelitian yang digunakan adalah penelitian kualitatif dengan pendekatan pohon masalah. Teknik analisis data dengan menggunakan analisis pohon masalah, analisis pohon sasaran dan analisis pohon alternative

\section{HASIL DAN PEMBAHASAN}

Pelaksanaan pembelajaran online yang telah belangsung cukup lama telah membawa dampak yang luar biasa bagi dunia pendidikan. Di daerah perkotaan mungkin tidak telalu memberi dampak namun di daerah pedesaan sangat terasa dampak yang dialami oleh guru, siswa dan orang tua. Pertama keterbatasan teknologi yang dialami oleh guru dan siswa. Sebagian guru mengalami kendala karena kurang memahami penggunaaan teknologi yang cocok untuk pembelajaran jarak jauh dan juga sulit untuk memantau perkembangan siswa. Demikian pula sebagian besar siswa yang belum mampu menggunakan teknologi dalam pembelajaran karena penuh dengan keterbatasan. Kedua sarana dan prasarana belum dapat menjamin keberlangsungan pembelajaran online. Ketiga akses dari internet yang sangat terbatas, jaringan tidak dapat menjangkau daerah pedalaman . Keempat biaya yang digunakan dalam pembelajaran online masih terbatas terutama biaya yang digunakan oleh siswa dalam pembelajaran online. Banyak orang tua mengeluh karena tidak mampu membeli fasilitas seperti laptop atau android serta biaya yang keluarkan untuk pembelian pulsa( Aji, 2020:397-398). 
Dengan adanya berbagai kendala yang dihadapi selama proses pembelajaran daring berlangsung maka pemerintah melakukan berbagai langkah, seperti pertemuan empat menteri untuk membahas dan menyikapi keadaan di masa pandemi yang masih terus belangsung sampai saat. Hasil kesepakatan empat menteri tersebut tertuang dalam SKB No1 tahun 2020 tentang pelaksanaan pembelajaran tatap muka di daerah Zona hijau bahwa memperbolehkan pelaksanaan pembelajaran tatap muka dengan tetap mempertimbangkan kesehatan dan keselamatan seluruh warga sekolah. Pelaksanaan pembelajaran tatap muka di SMK Negeri 2 Toraja Utara telah dimulai sejak bulan Februari sampai saat ini. Selama pelaksanaan tatap muka pembelajaran berlangsung dengan baik dan sampai hari ini semua warga SMK Negeri 2 Toraja Utara tetap dalam keadaan sehat.

Teknis pelaksanaan pembelajaran yang dilakukan sesuai dengan hasil keputusan rapat yang telah ditetapkan pimpinan sekolah bersama guru, orang tua dan komite sekolah bahwa 1) siswa dalam satu kelas dibagi menjadi 2 bagian(sesi), sesi pertama masuk pada minggu pertama dan sesi kedua masuk pada minggu kedua, begitu seterusnya bergiliran. 2) Jumlah siswa dalam satu kelas maksimal 18 orang untuk setiap sesi pembelajaran karena jumlah siswa per kelas normal 36 orang. 3)Durasi waktu yang digunakan siswa dalam belajar untuk setiap mata pelajaran adalah $2 \times 40$ menit . 4)Dalam satu hari di isi oleh 3 mata pelajaran dan tidak diberi istirahat di luar kelas. 5) Untuk kelas X dijadwalkan masuk pada hari Senin sampai Kamis, kelas XI masuk hari Rabu sampai Sabtu dan kelas XII masuk hari Senin, Selasa, Jumat dan Sabtu.6) Semua guru dan siswa harus mematuhi protokol kesehatan menggunakan masker dan sebelum masuk dan keluar kelas harus mencuci tangan. 7) Bel pergantian pembelajaran disetting sehingga disertai dengan informasi tentang protokol kesehatan. 8) Guru dan pegawai harus terlibat dalam pengawasan terhadap protokol kesehatan siswa. Jadi dari pengaturan inilah yang membuat pelaksanaan pembelajaran tatap muka di SMK Negeri 2 Toraja Utara berjalan dengan baik tanpa kendala dengan terus menerus melakukan evaluasi sampai pada pelaksanaan tatap muka penuh.

Kesiapan pelaksanaan pembelajaran tatap muka menjadi hal yang paling utama agar pelaksanaan berjalan dengan lancar. Proses persiapan pelaksanaan tatap muka di SMK Negeri 2 Toraja Utara tergambar pada diagram pohon masalah pohon sasaran dan pohon alternatif di bawah ini :

Analisis pohon masalah pada pembelajaran tatap muka di SMK Negeri 2 Toraja Utara

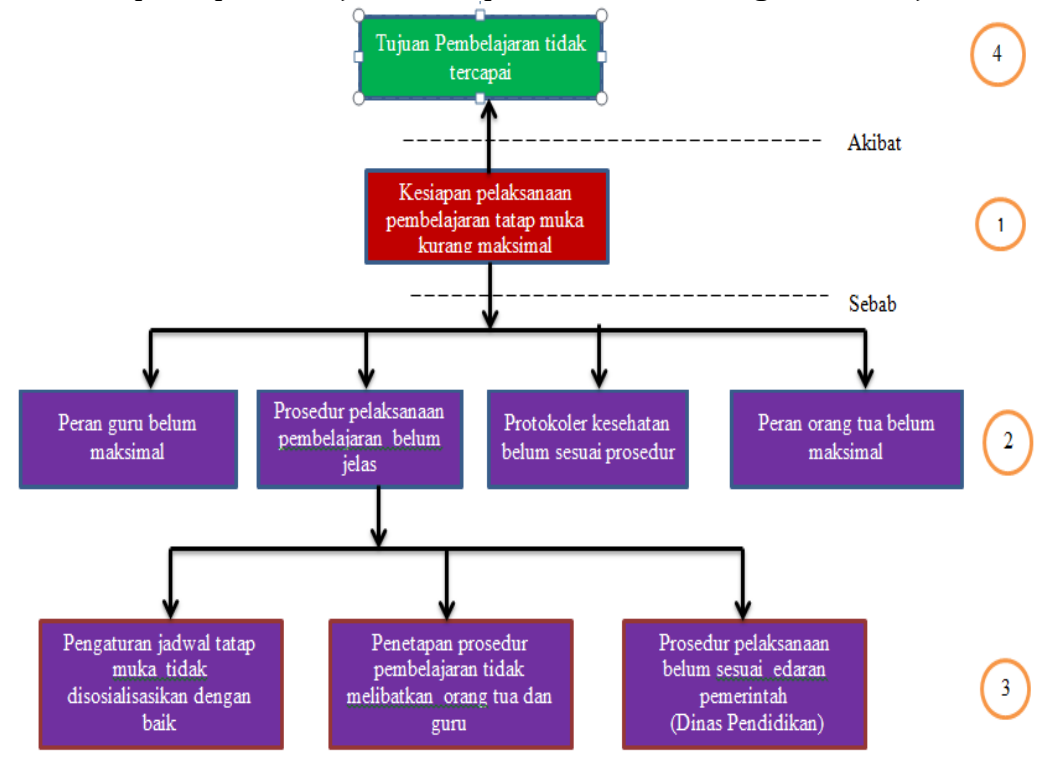

Gbr. 1 Diagram Pohon Masalah

Pada tahapan ini kegiatan yang dilakukan adalah menetapkan apa yang menjadi masalah utama jika pelaksanaan tatap muka dilaksanakan, setelah masalah utama sudah ditemukan maka ditetapkan apa penyebab dari masalah utama tersebut sekaligus kita menentukan penyebab utama 
dari masalah tersebut. Setelah penyebab utama sudah ditentukan maka ditentukan beberapa penyebab dari penyebab utama tadi. Dan bagian terakhir adalah menetapkan apa yang menjadi akibat dari permasalahan tersebut. Pada analisis pohon masalah ini dinyatakan dalam kalimat negatif. Pada analisis ini yang menjadi masalah utama adalah kesiapan pembelajaran tatap muka kurang maksimal penyebabnya antara lain peran guru belum maksimal, peran orang tua belum maksimal, prosedur pelaksanaan pembelajaran tatap muka belum jelas dan protokol kesehatan belum sesuai standard an yang menjadi penyebab utama dari permasalahan tersebut adalah prosedur pelaksanaan pembelajaran tatap muka belum jelas. Dari penyebab utama muncul beberapa penyebab lanjutan antara lain pengaturan jadwal tatap muka tidak disosialisasikan dengan baik, penetapan prosedur pembelajaran tidak melibatkan gurudan orang tua siswa, prosedur pelaksanaan belum sesuai dengan edaran pemerintah(Dinas Pendidikan) akibatnya tujuan pembelajaran tidak tercapai.

Analisis pohon sasaran pada pembelajaran tatap muka di SMK Negeri 2 Toraja Utara

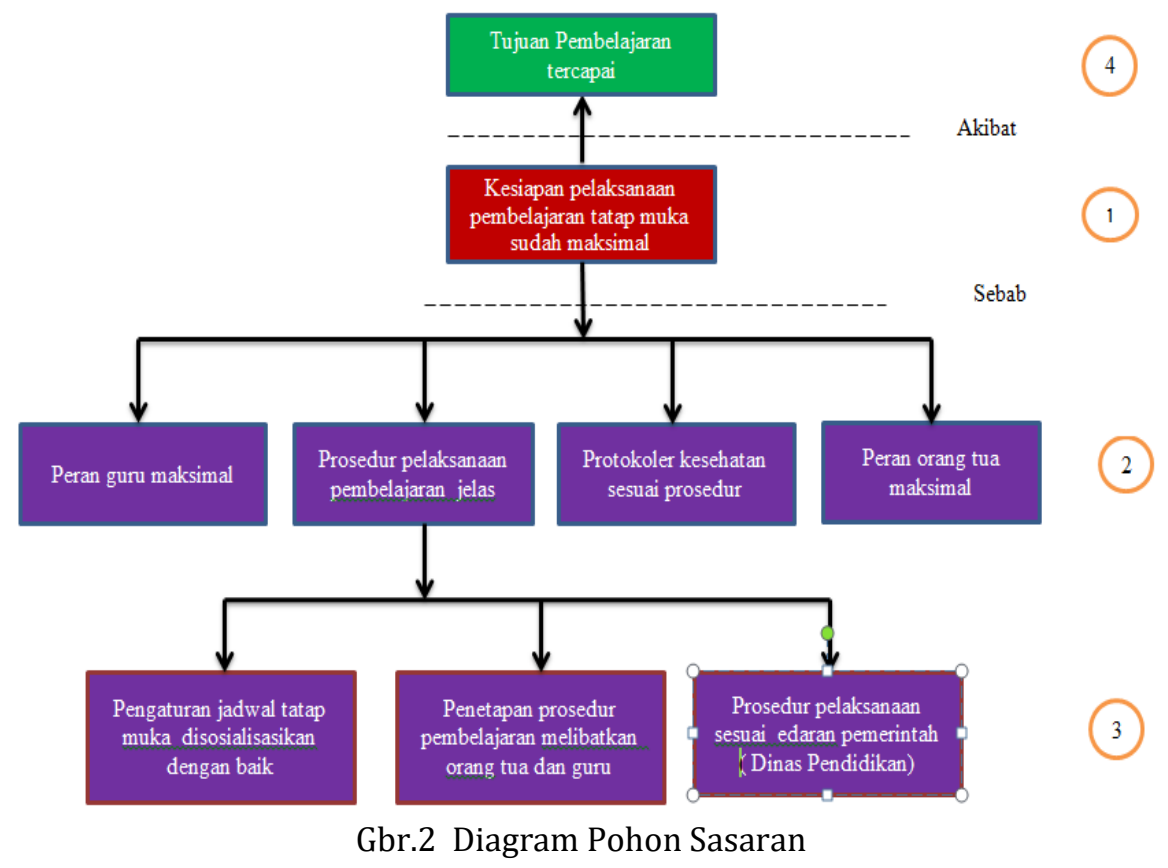

Setelah melakukan analisis pohon masalah maka selanjutnya dilakukan analisis pohon sasaran untuk mengetahui sasaran yang hendak dicapai. Pada tahapan ini kegiatan yang dilakukan sama dengan menetapkan apa yang menjadi sasaran utama jika pelaksanaan tatap muka dilaksanakan, setelah sasaran utama sudah ditetapkan maka ditetapkan pendukung dari sasaran yang hendak dicapai sekaligus menentukan pendukung utama dari sasaran yang hendak dicapai. Setelah pendukung utama sudah ditentukan maka ditentukan beberapa pendukung lanjutan dari pendukung utama tadi. Dan bagian terakhir adalah menetapkan apa yang menjadi akibat dari kegiatan tersebut. Pada analisis ini yang menjadi sasaran utama adalah kesiapan pembelajaran tatap muka sudah maksimal. Faktor yang mendukung antara lain peran guru maksimal, peran orang tua maksimal, prosedur pelaksanaan pembelajaran tatap muka jelas dan protokol kesehatan sesuai standard d an yang menjadi pendukung utama dari permasalahan tersebut adalah prosedur pelaksanaan pembelajaran tatap muka jelas. Prosedur pelaksanaan pembelajaran tatap muka jelas karena pengaturan jadwal tatap muka disosialisasikan dengan baik, penetapan prosedur pembelajaran melibatkan guru dan orang tua siswa dan prosedur pelaksanaan sesuai dengan edaran pemerintah(Dinas Pendidikan) sehingga tujuan pembelajaran tercapai.

Analisis pohon alternatif pada pembelajaran tatap muka di SMK Negeri 2 Toraja Utara 


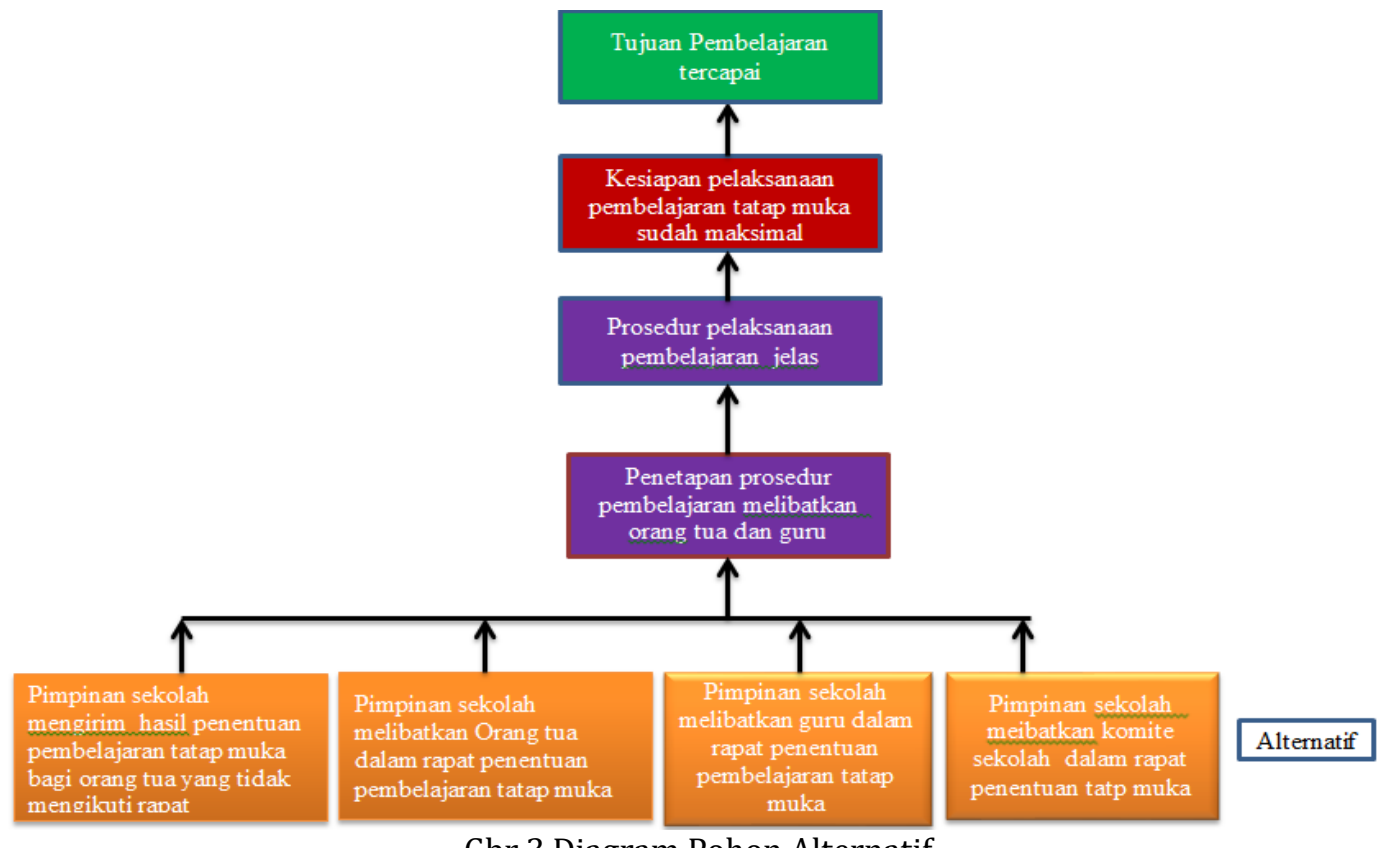

Gbr.3 Diagram Pohon Alternatif

Setelah analisis pohon sasaran dilakukan maka dilanjutkan dengan analisis pohon alternatif. Pada tahapan ini menganalisis alternatif-alternatif yang dapat menjadi solusi dari pendukung lanjutan. Langkah yang diambil pada penetapan prosedur pembelajaran agar dapat melibatkan orang tua adalah pimpinan sekolah melibatkan orang tua, guru dan komite sekolah dalam rapat penentuan pembelajaran tatap muka agar prosedur pelaksanaan jelas sehingga kesiapan pembelajaran tatap muka maksimal dan mengakibatkan tujuan pembelajaran dapat tercapai dengan baik

Jadi pelaksanaan pembelajaran tatap muka di SMK Negeri 2 Toraja Utara dapat berjalan dengan lancar dapat mencapai tujuan pembelajaran karena kesiapan pelaksanaan pembelajaran tatap muka jelas dengan adanya prosedur pelaksanaan pembelajaran yang jelas yang dilakukan melalui rapat melibatkan guru, orang tua, komite sekolah dengan mengikuti edaran dari pemerintah(Dinas Pendidikan)

\section{KESIMPULAN}

\section{Kesimpulan}

Berdasarkan hasil penelitian tersebut terbukti bahwa kesiapan pelaksanaan pembelajaran tatap muka di SMK Negeri 2 Toraja utara maksimal dikarenakan prosedur pembelajaran tatap muka jelas. Prosedur pembelajaran tatap muka jelas karena penetapan prosedur pembelajaran melibatkan guru dan orang tua. Penetapan prosedur pembelajaran melibatkan guru dan orang tua karena pimpinan sekolah melibatkan guru, orang tua siswa, komite sekolah pada rapat penentuan pelaksanaan pembelajaran tatap muka dan pimpinan sekolah akan mengirim hasil penentuan pembelajaran tatap muka bagi orang tua yang tidak mengikuti rapat

Implikasi

Pelaksanaan pembelajaran tatap muka di SMK Negeri 2 Toraja Utara pada masa pandemi dapat mencapai tujuan pembelajaran karena kesiapan pelaksanaan pembelajaran tatap muka maksimal.

Saran 
Agar pelaksanaan pelaksanaan pembelajaran tatap muka dimasa pandemi dapat mencapai tujuan pembelajaran maka sebaiknya pimpinan sekolah melibatkan guru, orang tua dan komite sekolah pada pada rapat penentuan pelaksanaan pembelajaran tatap muka dan mengirim hasil penentuan pembelajaran tatap muka bagi orang tua yang tidak mengikuti rapat.

\section{DAFTAR PUSTAKA}

1. Aji Syah Halal Rizqon, "Dampak Covid-19 pada Pendidikan Indonesia: Sekolah, Keterampilan dan Proses Pembelajaran", Jurnal Budaya Sosial dan Syar'I, Volume 07 Nomor 05, (Jakarta: FSH UIN Syarif Hidayatullah 2020), hal. 397-398

2. Anggrawan, A. (2019). Analisis deskriptif hasil belajar pembelajaran tatap muka dan pembelajaran online menurut gaya belajar mahasiswa. MATRIK: Jurnal Manajemen, Teknik Informatika Dan Rekayasa Komputer, 18(2), 339-346.

3. Gunawan, Suranti, N. M. Y., \& Fathoroni. (2020). Variations of Models and Learning Platforms for Prospective Teachers During the COVID-19 Pandemic Period. Indonesian Journal of Teacher Education, 1(2), 61-70.

4. https://edukasi.kompas.com/read/2021/03/31/071742471/jadwal-tvri-belajar-dari-rumahrabu-31-maret-2021

5. Herliandry, L. D., Nurhasanah, N., Suban, M. E., \& Kuswanto, H. (2020). Pembelajaran pada masa pandemi covid-19. JTP-Jurnal Teknologi Pendidikan, 22(1), 65-70.

6. Jamal, S. (2020). Analisis Kesiapan Pembelajaran E-Learning Saat Pandemi Covid-19 Di Smk Negeri 1 Tambelangan. Jurnal Nalar Pendidikan, 8(1), 16-22.

7. Keputusan Bersama 4 Menteri. 2020. Panduan Penyelenggaraan Pembelajaran pada Tahun Ajaran 2020/2021 dan Tahun Akademik 2020/2021 di Masa Pandemi Coronavirus Disease 2019 (Covid-19). Jakarta. Kemendikbud RI.

8. Norman S.(2016)."Traditional Education and Advantages of Online Learning,"

9. Nugroho, M. M., Syamsuar, A., Syamsuar, A., Yunaryo, H. M. A., Pramesti, L. A., Darmamulia, M. A., ... \& Ernawati, E. ANALISIS KESIAPAN PELAKSANAAN KEGIATAN PEMBELAJARAN TATAP MUKA DI INDONESIA PADA TAHUN 2021. Journal Publicuho, 3(4), 523-542. ISSN 2621-1351 (online), ISSN 2685-0729 (print)

10. Nurlatifah, N., Ahman, E., Machmud, A., \& Sobandi, A. (2021). EFEKTIVITAS PEMBELAJARAN ONLINE VERSUS TATAP MUKA. Pedagonal: Jurnal Ilmiah Pendidikan, 5(1), 15-18. e-ISSN : 2550-0406.

11. Rizqon Halal Syah Aji. (2020). "Dampak Covid-19 pada Pendidikan Indonesia: Sekolah, Keterampilan dan Proses Pembelajaran", Jurnal Budaya Sosial dan Syar'I, Volume 07 Nomor 05, (Jakarta: FSH UIN Syarif Hidayatullah 2020), hal. 397-398

12. Sabiq, A. F. (2020). Persepsi Orang Tua Siswa tentang Kegiatan Belajar di Rumah sebagai Dampak Penyebaran Covid 19. Civic-Culture: Jurnal Ilmu Pendidikan PKn dan Sosial Budaya, 4(1 Extra), 1-7. 
13. Shaleh, M., \& Anhusadar, L. (2021). Kesiapan Lembaga PAUD dalam Pembelajaran Tatap Muka pada New Normal. Jurnal Obsesi: Jurnal Pendidikan Anak Usia Dini, 5(2), 2158-2167. ISSN: 2549-8959 (Online) 2356-1327 (Print)

14. Wekke, I. S., \& Saleh, A. M. (2020). Pembelajaran di Masa Pandemi: Tidak Hanya Metode Daring Saja. 